\title{
Household Demand for Fruits and Vegetables in Rural and Urban South-Western Nigeria
}

\author{
Rebecca Ibe ${ }^{1}$, Mohammed Rahji ${ }^{2}$, Adetola Adeoti ${ }^{2}$, Kemisola Adenegan $^{2}$ \\ ${ }^{1}$ National Horticultural Research Institute, Jericho Reservation Area, Nigeria \\ ${ }^{2}$ Department of Agricultural Economics, University of Ibadan, Nigeria
}

\begin{abstract}
In spite of the enormous benefits of fruits and vegetables, studies have shown that their consumption in Nigeria is far below the recommended daily intake therefore, this study investigated the factors influencing the demand for fruits and vegetables among households in rural and urban South-western Nigeria. Data were sourced from 152 rural and 259 urban households, respectively with the aid of a semi-structured questionnaire and were analysed using descriptive statistics and the quadratic almost ideal demand system model. Household size and location, sex and years of education of household heads influenced the demand for fruits and vegetables. Both rural and urban households considered the demand for fruits and vegetables to be luxury goods. Rural households were more responsive to changes in own-prices of fruits and vegetables than their urban counterpart. Fruits and vegetables were "net substitutes" in the rural and "complements" in the urban.
\end{abstract}

\section{Keywords}

Fruits, vegetables; household demand; demand elasticity; quadratic almost ideal demand system.

Ibe R., Rahji, M., Adeoti, A. and Adenegan, K. (2020) "Household Demand for Fruits and Vegetables in Rural and Urban South-Western Nigeria", AGRIS on-line Papers in Economics and Informatics, Vol. 12, No. 3, pp. 23-35. ISSN 1804-1930. DOI 10.7160/aol.2020.120303.

\section{Introduction}

Fruits and vegetables are rich in vitamins, minerals, and dietary fiber and are also low in calorie required for the normal functioning of human body (Uusiku et al., 2010). The micronutrients supplied by fruits and vegetables are also vital for the optimal functioning of the gastro-intestinal tract as they also enable the body to use other nutrients required for its normal function like energy from fats and carbohydrate (Banwat et al., 2012). Despite the nutritional importance of fruits and vegetables, their intake is still far below the minimum recommendation of the World Health Organization (WHO) of $400 \mathrm{~g}$ per capita per day (Ruel et al., 2005; Banwat et al, 2012; Ogundari and Arifalo, 2013; Pem and Jeewon, 2015) in both developed and developing countries. It is estimated that people worldwide eat just 20-50\% of the recommended minimum (Food and Agriculture Organization (FAO), 2006). According to a FAO report (2013), combined annual fruit and vegetable consumption in Africa is less than $100 \mathrm{~kg}$ per person, which amounts to $250 \mathrm{~g}$ per person per day. Increased consumption of fruits and vegetables has been recommended as a key component of a healthy diet for the prevention of non-communicable chronic diseases (Ishdorg et al., 2013; Wang et al., 2014). Low consumption of fruits and vegetables has also been ranked the sixth major risk factor for mortality in the world (WHO, 2012).

Furthermore, in spite of the FAO/WHO ' 5 A day' message for fruit and vegetable consumption, a large gap still exists between the recommended and actual intake and many people worldwide are not measuring up with the expected quantity or variety (Krebs-Smith et al., 2010). As reported in a data from the European Food Safety Authority (EFSA) database (2013) and the Global Environment Monitoring System (GEMS)/Food database (2015), average fruit and vegetable intake is not positively linked to the status of the country since greater consumption could be observed in developing countries such as Uganda and People's Republic of China (PR China) compared to developed countries such as Denmark, Germany, the United Kingdom (UK) and France. In the United States (US), mean fruit and vegetable intake was 
$189.30 \mathrm{~g} /$ day and $255 \mathrm{~g}$ /day respectively (Centre for Disease Control and Prevention, 2013). Fruits and vegetables were consumed in the amount of $146.81 \mathrm{~g} /$ day and $176.96 \mathrm{~g} /$ day respectively in Hong Kong accounting for a total of $324 \mathrm{~g} /$ day (The Chinese University of Hong Kong, 2010), while $209 \mathrm{~g}$ per day and $228.6 \mathrm{~g}$ /day fruit and vegetable intake was reported among adults (Mensik et al., 2013). In Malaysia, fruit and vegetable intake was $179 \mathrm{~g} /$ day and $133 \mathrm{~g} /$ day, respectively (Izzah et al., 2012).

In Nigeria, empirical evidences indicated that expenditure on fruits and vegetables has been very low. According to a report released by the National Bureau of Statistics (NBS) in 2012, only $1.39 \%$ and $11.49 \%$ of the total household food expenditure were spent on fruits and vegetables, respectively in $2009 / 10$ compared to $20.99 \%$ and $20.24 \%$ for cereals and tubers respectively. When disaggregated further, rural households spent $1.34 \%, 11.59 \%, 22.58 \%$ and $20.73 \%$ of total household food budget on fruits, vegetables, cereals, tubers and plantain respectively, while in the urban $1.52 \%, 11.23 \%, 16.92 \%$ and $18.97 \%$ were expended on fruits, vegetables, cereals, tubers and plantain respectively. These figures indicate the fact that in Nigeria, expenditure on fruits and vegetables is low when compared with cereals and tubers. However, the major determinants for the low expenditure on fruits and vegetables in Nigeria have not been ascertained.

Although considerable number of researchers such as Akinleye, 2009; Muhammad-Lawal et al. (2011), Fashogbon and Oni (2013), Ogundari and Arifalo (2013), had examined the determinants of food demand/consumption in Nigeria however, studies on determinants of the demand for different groups of fruits and vegetables are scarce. This study also becomes appropriate from the methodological point of view because, most studies on the determinants of fruit and vegetable demand/consumption (Ruel et al., 2005; Yen and Tan, 2011; Ogunniyi et al., 2012; Ogundari and Arifalo, 2013; Ohen et al., 2014; made use of conventional food demand models such as single demand equations, linear expenditure systems, Rotterdam model, Transcendental logarithmic (Translog) model and the Almost Ideal Demand Systems (AIDS) for analysis. However, only few studies (such as Mutuc et al., 2007; Tey et al., 2009; Otunaiya and Shittu, 2014) have attempted using the Quadratic Almost Ideal Demand System (QUAIDS) to model demand for vegetables in developing countries. This study therefore extends the frontier of literature on factors influencing fruit and vegetable demand among households in Nigeria. Information generated from this study will assist food producers/marketers to identify target consumer groups of fruit and vegetable items as well as guide policy makers in formulating public health and dietary promoting programmes.

\section{Materials and methods}

\section{Study area}

The study was conducted in South-western Nigeria between April and May 2013. Southwestern Nigeria is one of the six geopolitical zones in Nigeria; it falls on latitude $6^{0}$ to the North and $4^{\circ}$ to the South and is marked by longitude $4^{0}$ to the West and $6^{0}$ to the East. The zone is made up of six states namely Ekiti, Lagos, Ogun, Ondo, Osun and Oyo with a total population of 27,581,992 and predominantly agrarian (National Population Commission (NPC), 2006).

\section{Source of data}

The study made use of primary data which was sourced from respondents with the aid of a semistructured questionnaire administered to household heads in rural and urban South-western Nigeria between April and May 2013. Information elicited from the respondents (household head or spouse) includes household heads' demographic and socioeconomic characteristics, and household's fruit and vegetable expenditure using seven days memory recall. The fruit and vegetable groups considered were leafy vegetables, fruit vegetables, root and bulb vegetables, herbaceous/perennial fruits and tree fruits. The classification was based on that of Matthew and Karikari (1990) and Pennington and Fisher (2009). The composition of the fruit and vegetable groups used for this study can be found in Appendix 1.

\section{Sampling procedure}

Data were collected from selected households in the study area between April and May 2013 using multi-stage sampling procedure. The first stage was the random selection of Ogun and Osun States out of the six states that constitutes the South-western Nigeria (see Figure 1) for the map of Nigeria showing the South-western zone and the selected states). The second stage was the random selection of 10 Local Government Areas (LGAs, $20 \%$ of LGAs in the two States) out of the 50 LGAs (Ogun = 20; Osun = 30) that make up the two States due to paucity of fund to cover all the LGAs. The selection of LGAs 
per State was proportionate to the size of LGAs in each State. Four (4) and six (6) LGAs were selected from Ogun and Osun states, respectively because Osun has more LGAs (30) than Ogun (20) (NPC, 2006). The third stage was the random selection of one rural and one urban community from each of the selected LGAs. In the fourth stage, 450 households were randomly selected from the total number of households in the two States (1,611,283 households) proportionate to the number of households in each state $($ Ogun $=880,970$; Osun $=730,313)$. Following this, a total of 246 and 204 households were selected from Ogun and Osun States, respectively (see appendix 2) based on the fact that Ogun has a higher number of households compared to Osun as indicated in the 2006 National Population Census figures of the Federal Republic of Nigeria (NPC, 2006). Sixty percent (60 \%) of the households selected from each LGA were sampled from the urban communities, while $40 \%$ was from the rural because it is believed that households are more in the urban centers due to prevailing rural-urban migration in Nigeria (Ogunmakinde et al., 2015). However, out of the 450 questionnaire administered, only 411 were found useful for analysis due to incomplete responses.

\section{Estimation procedure}

The study employed a two-step estimation procedure developed by Shonkwiler and Yen (1999) where the Inverse Mill's Ratio (IMR) for the various fruit and vegetable groups were first estimated from a Probit model and then incorporated into the demand equation. This estimation procedure takes into account correction for the possible sample selection bias created by the presence of zero expenditure for fruit and vegetable types reported by some households. In the first step, a Probit regression was estimated, which determines the probability that a given household purchased a fruit and vegetable item/group or not as observed in the studies of Mutuc et al. (2007) and Tey et al. (2009).

In the second step, expenditure share equations were specified as a quadratic extension of the Almost Ideal Demand System (QUAIDS) model with the IMRs included as instrumental variables. If the coefficient of IMR is statistically significant in the second step, then the subsample of purchasing households represents itself and excludes non-purchasers from the analysis. The estimated model therefore suffers from selectivity bias. However, if the coefficient of the IMR is insignificant, it means there is

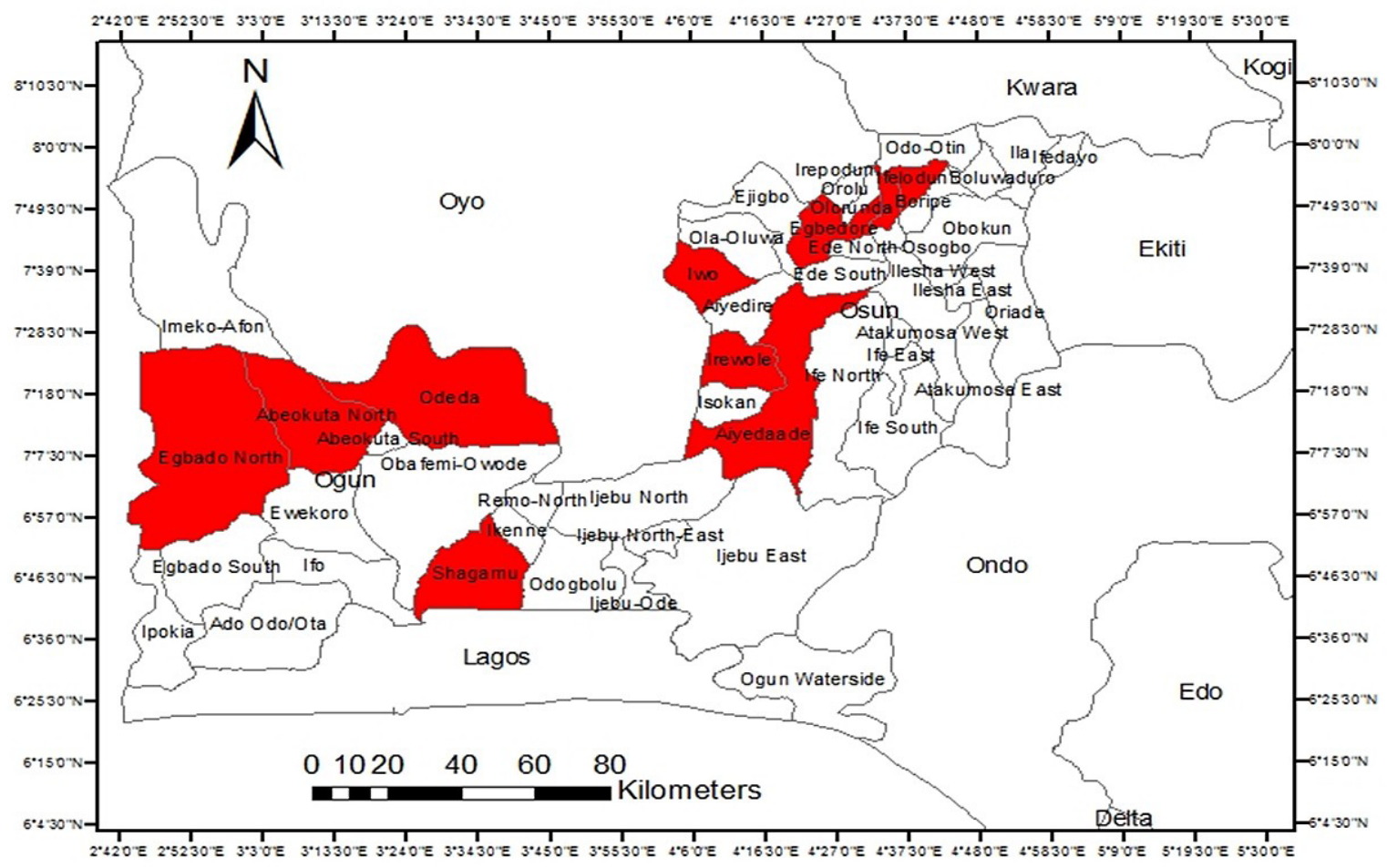

Source: The author generated the map with the help of a cartographer. The figure is a map of the study area highlighting the locations where the survey was conducted

Figure 1: Map of South-western zone of Nigeria showing the selected LGAs. 
no selectivity bias in the data. This means that the sub-sample of households purchasing fruits and vegetables are representative of the population.

The Quadratic Almost Ideal Demand System (QUAIDS) derived by Banks et al., (1996 and 1997) was employed to estimate price and income elasticities for the households as well as to determine the factors influencing households' expenditure on the fruit and vegetable items. QUAIDS is a rank three budget share system that is quadratic in the logarithm of total expenditure. It has the attractive property of allowing goods to have the characteristics of luxuries at low levels of total expenditure, and necessities at higher levels.

The QUAIDS which is derived from a generalization of the Price Independent Generalised Logarithmic (PIGLOG) preferences starts from an indirect utility function of the form:

$\ln V=\left\{\left[\frac{\ln m-\ln a(p)}{b(p)}\right]^{-1}+\lambda(p)\right\}^{-1}$

Where the term $[\ln m-\ln a(p)]$ is the indirect utility function of the PIGLOG demand system (that is, a system with budget shares linear in log total expenditure), $m$ is the total expenditure, and $a(p)$, $b(p)$ and $\lambda(\mathrm{p})$ are functions of the vector of prices $p$. To ensure the homogeneity property of the indirect utility function, it is required that $a(p)$ is homogenous of degree one in prices, and $b(p)$ and $\lambda(p)$ homogenous of degree zero in prices. The $\ln a(p)$ given in equation (1) has the Translog form:

$\ln a(p)=\alpha_{0}+\sum_{i=1}^{j} \alpha_{i} \ln p_{i}+\frac{1}{2} \sum_{i=1}^{j} \sum_{i=1}^{j} \gamma_{i j} \ln p_{j}$

and $b(p)$ is the simple Cobb-Douglas price aggregator defined as:

$$
\begin{aligned}
& b(p)=\prod_{i=1}^{j} p_{i}^{\beta_{i}} \\
& \lambda(p)=\sum_{i=1}^{K} \lambda_{i} \ln p_{i}, \text { where } \sum_{i=1}^{K} \lambda_{i}=0
\end{aligned}
$$

Where $i=1, \ldots, \mathrm{K}$ denotes the number of goods entering the demand model.

Application of Roy's identity or Shephard's Lemma to the indirect utility function (equation 4) gives the QUAIDS model expenditure share as:

$\omega_{i}=\alpha_{i}+\sum_{j=1}^{K} \gamma_{i j} \ln p_{j}+\beta_{i} \ln \left[\frac{m}{a(p)}\right]+\frac{\lambda_{i}}{b(p)}\left\{\ln \left[\frac{m}{a(p)}\right]\right\}^{2}$

To control for varying preference structures and heterogeneity across households, we incorporate demographic variables (z) into the QUAIDS model (equation 5) through the linear demographic translating method (Pollak and Wales, 1981). The expenditure share then becomes:

$$
\omega_{i}=\alpha_{i}+\sum_{j=1}^{K} \gamma_{i j} \ln p_{j}+\beta \ln \left[\frac{m}{a(p)}\right]+\frac{\lambda_{i}}{b(p)}\left\{\ln \left[\frac{m}{a(p)}\right]\right\}^{2}+\sum_{s=1}^{L} \delta_{i s} z_{s}+u_{i}
$$

Where $z_{s}=\left(z_{1}, \ldots, z_{L}\right)$ is a set of demographic variables, $w_{i}$ is the share of group expenditure allocated to product $i, p_{i}$ is the price of product $i$, and $m$ is the per capital expenditures on all commodities. Also, when the IMRs generated from the Probit model are incorporated into the expenditure share equation, it becomes:

$$
\begin{aligned}
\omega_{i} & =\alpha_{i}+\sum_{j=1}^{K} \gamma_{i j} \ln p_{j}+\beta_{i} \ln \left[\frac{m}{a(p)}\right]+\frac{\lambda_{i}}{b(p)}\left\{\ln \left[\frac{m}{a(p)}\right]\right\}^{2} \\
& +\sum_{s=1}^{L} \delta_{i s} z_{s}+\pi_{i} I M R_{i}+u_{i}
\end{aligned}
$$

Where $\alpha_{i}, \lambda, \beta, \gamma$ are parameters to be estimated

$\alpha_{i}=$ average value of expenditure share in the absence of price and income effects.

$\beta=$ parameter that determines whether goods are luxuries or necessities

$\gamma_{i j}=$ effects on the budget of item $i$ of 1 percent change in the prices of items in group $j$

$P_{j}=$ price of item $j$

$\delta_{j}=$ vector of socioeconomic and demographic variables

$\pi_{i}=$ vector of IMRs

$u_{i}=$ error term

As with the original AIDS model, the theoretical restrictions of adding-up, homogeneity, and symmetry in the QUAIDS model are expressed in terms of its parameters. Adding-up requires $\Sigma_{i} w_{i}=1$, and can be expressed in terms of model parameters as:

$\sum_{i=1}^{k} \alpha_{i}=1 ; \sum_{i=1}^{k} \beta_{i}=0 ; \sum_{i=1}^{k} \lambda_{i}=0 ; \sum_{i=1}^{k} \gamma_{i j}=0 \quad \forall_{j}$

Since Marshallian demands are homogenous of degree zero in $(\mathrm{p}, \mathrm{m})$,

$\sum_{j=1}^{k} \gamma_{i j}=0 \quad \forall j$

Slutsky symmetry implies that:

$\gamma_{i j}=\gamma_{j i} \quad \forall{ }_{i, j}$ 
Expenditure share for each fruit and vegetable group was calculated thus:

$W_{G}=\frac{X_{G}}{X}=$ the expenditure share of group $\mathrm{G}(11)$

$X_{G}=\sum p_{G i} q_{G i}$

$X_{G}=$ total expenditure of group $\mathrm{G}$

$P_{G i}$ and $q_{G i}=$ the price and quantity of ith good in group $\mathrm{G}$

$G=1$ to 5 (see Table1)

STATA 13.1 software was used to run the QUAIDS. In order to avoid a singular covariance matrix, all the five expenditure share equations were specified, while the QUAIDS programme automatically omits one of the demand equations by itself and recovers it in the course of the analysis through the adding-up restrictions.

Elasticities were obtained by first differentiating the expenditure share equation (7) with respect to $\ln m$ and $\ln p j$ respectively to obtain:

$\mu_{i}=\frac{\partial \omega_{i}}{\partial \ln x}=\beta_{i}+\frac{2 \lambda_{i}}{b(p)}\left\{\ln \left[\frac{m}{a(p)}\right]\right\}$

$\mu_{i j} \equiv \frac{\partial \omega_{i}}{\partial \ln p_{j}}=\gamma_{i j}-\mu_{i}\left(\alpha_{j}+\sum_{k} \gamma_{j k} \ln p_{k}\right)-\frac{\lambda_{i} \beta_{j}}{b(p)}\left\{\ln \left[\frac{m}{a(p)}\right]\right\}^{2}$

The expenditure elasticity was derived as follows:

$e_{i}=\frac{\mu_{i}}{\omega_{i}}+1$

The uncompensated or Marshallian price elasticity is given by

$e_{i j}^{u}=\frac{\mu}{w_{i}}-\delta_{i j}$

where $\delta_{i j}$ is the Kronecker delta which is equal to one when $i=j$, otherwise $\delta_{i j}=0$. Using the Slutsky equation, the compensated or Hicksian price elasticities was calculated and used to assess the symmetry and negativity conditions by examining the matrix with elements $w_{i}\left[e^{c}{ }_{i j}\right]$ which should be symmetric and negative semidefinite in the usual way.

$e_{i j}^{c}=e_{i j}^{u}+w_{j} e_{i}$

\section{Results and discussion}

\section{Zero expenditure}

When modelling demand using micro data, it is typical to observe a significant number of households that purchase zero quantity of some of the items (or commodities) during the survey period (Bopape, 2006). A sample with a large number of non-purchasing households poses a number of econometric challenges. Table 1 reports the percentages of non-purchasing households vis a vis the fruit and vegetable groups. Herbaceous fruits were the least purchased by rural and urban households followed by tree fruits indicating that, households irrespective of their location tend to purchase more of vegetable items/categories than fruits. However, the values are higher for rural households compared to their urban counterparts indicating that, urban households purchase fruits and vegetables more than rural households.

\begin{tabular}{l|c|c}
\hline Fruit and vegetable group & Rural $(\mathrm{n}=152)$ & Urban $(\mathrm{n}=259)$ \\
& Z.E & Z.E \\
\hline Leafy vegetables & 25.7 & 14.3 \\
Fruit vegetables & 8.6 & 12.7 \\
Root and bulb vegetables & 30.3 & 29.7 \\
Herbaceous fruits & 61.2 & 42.5 \\
Tree fruits & 55.9 & 35.9 \\
\hline
\end{tabular}

Note: Z.E stands for zero expenditure. Figures are measured in percentages.

Source: Field survey 2013

Table 1: Distribution of households with zero fruit and vegetable expenditure.

\section{Budget shares, quantities and prices}

Results in Table 2 showed that on the average, quantity of fruits and vegetables purchased by rural and urban households on monthly basis were far below the WHO recommendation of $12 \mathrm{~kg}$ per capita per month (400g per capita per day). It is also evident from Table 2 that, households spent the largest part of their fruit and vegetable budget on fruit vegetables, while the least was herbaceous and tree fruits in rural and urban, respectively. The reason may be that fruit vegetables were important items in the fruit and vegetable basket of the households. Furthermore, prices of most of the fruits and vegetable groups were higher in the urban than in the rural resulting in higher expenditure shares for fruits and vegetables among urban households. This result supports the findings of Abdulai and Aubert (2004) which states that, households in urban areas expend more on fruits and vegetables relative to their rural counterpart. Apart from higher prices, the reason could also be attributed to the fact that urban households understand the importance of fruits and vegetables in diets than rural households. 


\begin{tabular}{|l|c|c|c|c|c|c|}
\hline $\begin{array}{l}\text { Fruit and } \\
\text { vegetable } \\
\text { group }\end{array}$ & \multicolumn{2}{|c|}{ Expenditure shares (\%) } & \multicolumn{2}{|c|}{ Quantity (Kg) } & \multicolumn{2}{c|}{ Price (N/Kg) } \\
\hline & Rural & Urban & Rural & Urban & Rural & Urban \\
\hline LVs & $17.0(0.18)$ & $18.8(0.19)$ & 5.31 & 5.47 & 78.65 & 89.59 \\
\hline t-value & -0.973 & & & & & \\
\hline FrVs & $52.0(0.27)$ & $40.1(0.24)$ & 7.67 & 9.43 & 176.99 & 174.98 \\
\hline t-value & $4.455^{* * *}$ & & & & & \\
\hline RBVs & $14.5(0.19)$ & $15.3(0.16)$ & 7.00 & 5.46 & 67.93 & 69.58 \\
\hline t-value & -0.440 & & & & & \\
\hline HFs & $7.8(0.15)$ & $13.6(0.19)$ & 0.51 & 2.48 & 87.48 & 82.86 \\
\hline t-value & $-3.401^{* * *}$ & & & & & \\
\hline TFs & $8.7(0.16)$ & $12.2(0.18)$ & 6.07 & 4.43 & 45.78 & 49.49 \\
\hline t-value & $-1.969^{*}$ & & & & & \\
\hline
\end{tabular}

Note: $L V s=$ leafy vegetables; FrVs = fruit vegetables; RBVs = root and bulb vegetables;

HFs $=$ herbaceous fruits; TFs $=$ tree fruits; standard deviations are in parenthesis; $*$ and $* * *$, represents

$1 \%$ and $10 \%$ level of significant, respectively; $\$$ is the Naira, Nigerian currency; US \$ $1=158.27$

at the time of the study

Source: Estimates of data analysis (descriptives)

Table 2: Expenditure shares, quantities and prices of fruits and vegetables.

\section{Determinants of household demand for fruits and vegetables}

The factors influencing households' demand for fruits and vegetables using the QUAIDS model are presented in Tables 3 and 4. The coefficient of $\operatorname{lnEXPD}^{2}$ for rural households (Table 3 ) is statistically significant for the fruit vegetables, root and bulb vegetables and tree fruits equations indicating that the response of their demand to increase in expenditure was non-linear. On the other hand, in the urban (Table 4) only the coefficient of $\operatorname{lnEXPD}^{2}$ for leafy vegetables, herbaceous fruits and tree fruits equations were statistically significant. Also, IMR was only significant in the budget share equation for leafy vegetables in the rural (Table 3) and that of leafy vegetables and fruit vegetables in the urban (Table 4) indicating that their inclusion was meaningful.

Considering the effect of household demographic and socio-economic variables on fruit and vegetable demand, results revealed that their effects varied. Results in Tables 3 and 4 reveals that prices of fruits and vegetables, access to credit and years of schooling of household head influenced household demand for fruits and vegetables in the rural, while the determinants in the urban were prices of fruits and vegetables, sex and years of education of household heads, household size and access to credit. For example, in the rural, years of schooling of household head had inverse relationship with household demand for tree fruits (Table 3) implying that households do not necessarily have to attain a higher education or access more credit before demanding for tree fruits. This suggests that, households might need more of nutrition education rather than formal education. On the other hand, sex of household head had positive influence on the demand for leafy vegetables among the urban households (Table 4). The implication is that male-headed households demand more of leafy vegetables which conforms to the findings of Nambiar et al., (2014) in Uganda that households with male heads spend less on fruit, compared to those with female heads. 


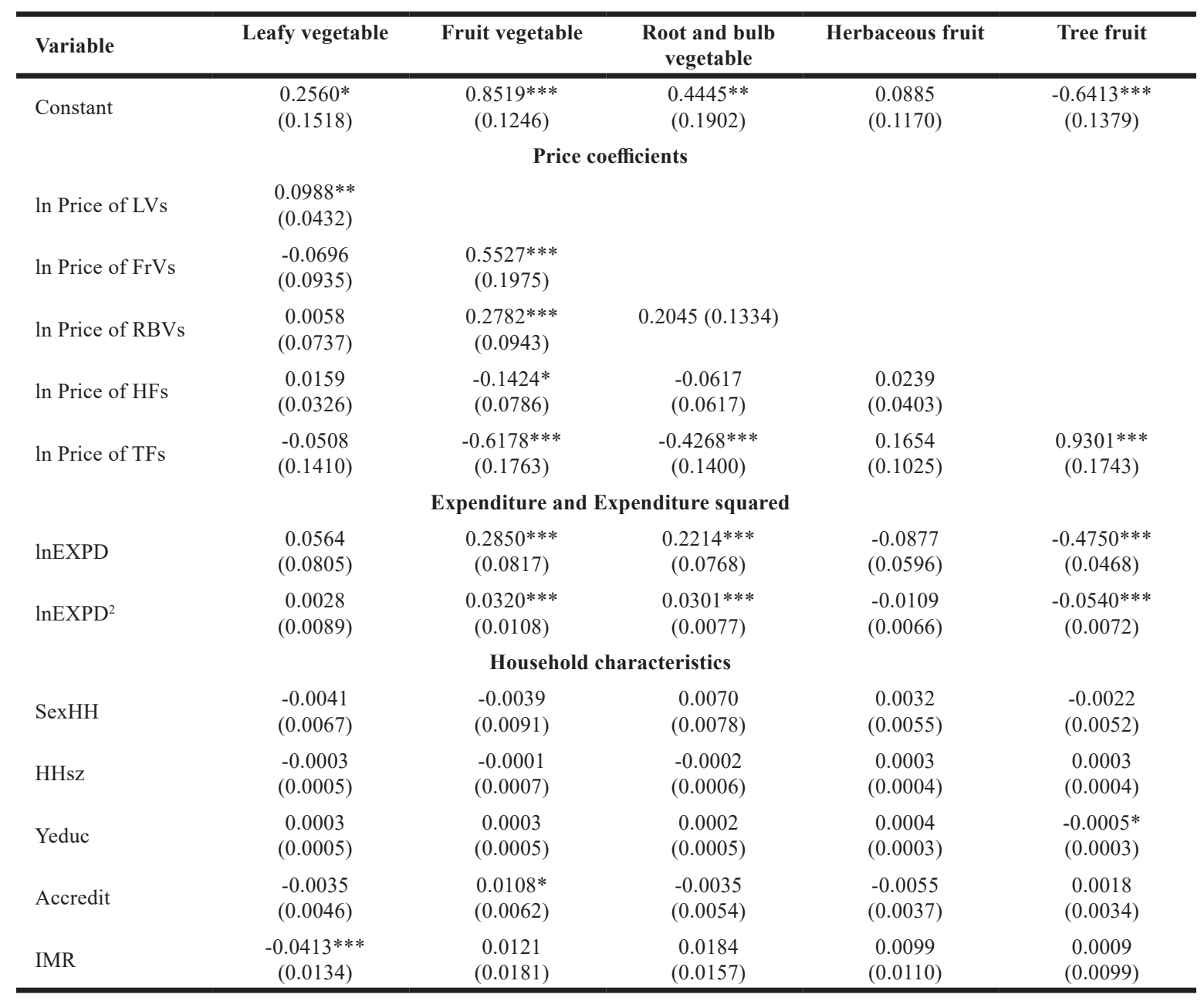

Note:***,**,* indicate level of significance at $1 \%, 5 \%$, and $10 \%$ respectively. Standard errors are in parenthesis.

ln = Logarithm; LVs = leafy vegetable; FrVs = fruit vegetable; RBVs = root and bulb vegetable; HFs = herbaceous fruit; TFs = tree fruit; $\operatorname{lnEXPD}=$ logarithm of total fruit and vegetable expenditure; $\operatorname{lnEXP}{ }^{2}=$ square of logarithm of total fruit and vegetable expenditure; $\mathrm{IMR}=$ Inverse Mills Ratio; SexHH = sex of household head; HHsz = household size; Yeduc $=$ years of schooling; Accredit = access to credit facility.

Source: Estimates from QUAIDS model

Table 3: Determinants of demand for fruits and vegetables (Rural).

\begin{tabular}{|c|c|c|c|c|c|}
\hline Variable & Leafy vegetable & Fruit vegetable & $\begin{array}{c}\text { Root and bulb } \\
\text { vegetable }\end{array}$ & Herbaceous fruit & Tree fruit \\
\hline Constant & $\begin{array}{c}0.2090 \\
(0.2869)\end{array}$ & $\begin{array}{c}1.1686 * * * \\
(0.2938)\end{array}$ & $\begin{array}{c}1.0426 * * * \\
(0.2850)\end{array}$ & $\begin{array}{c}0.7208 * * \\
(0.3166)\end{array}$ & $\begin{array}{c}-2.1412 * * * \\
(0.1684)\end{array}$ \\
\hline \multicolumn{6}{|c|}{ Price coefficients } \\
\hline In Price of LVs & $\begin{array}{l}0.0987^{*} \\
(0.0565)\end{array}$ & & & & \\
\hline In Price of RBVs & $\begin{array}{c}0.0407 \\
(0.0447)\end{array}$ & $\begin{array}{c}0.0222 \\
(0.0450)\end{array}$ & $\begin{array}{l}0.1497 * \\
(0.0779)\end{array}$ & & \\
\hline In Price of HFs & $\begin{array}{c}0.0302 \\
(0.0515)\end{array}$ & $\begin{array}{l}0.0880 * \\
(0.0527)\end{array}$ & $\begin{array}{c}0.0885 \\
(0.0551)\end{array}$ & $\begin{array}{c}0.1251 \\
(0.1047)\end{array}$ & \\
\hline
\end{tabular}

Note:***,*** indicate level of significance at $1 \%, 5 \%$, and $10 \%$ respectively. Standard errors are in parenthesis.

ln = Logarithm; LVs = leafy vegetable; FrVs = fruit vegetable; RBVs = root and bulb vegetable; HFs = herbaceous fruit; TFs = tree fruit; $\operatorname{lnEXPD}=$ logarithm of total fruit and vegetable expenditure; $\operatorname{lnEXPD}{ }^{2}=$ square of logarithm of total fruit and vegetable expenditure; IMR = Inverse Mills Ratio; SexHH = sex of household head; HHsz = household size; Yeduc = years of schooling; Accredit = access to credit facility.

Source: Estimates from QUAIDS model

Table 4: Determinants of demand for fruits and vegetables (Urban) (To be continued). 


\begin{tabular}{|c|c|c|c|c|c|}
\hline Variable & Leafy vegetable & Fruit vegetable & $\begin{array}{c}\text { Root and bulb } \\
\text { vegetable }\end{array}$ & Herbaceous fruit & Tree fruit \\
\hline \multicolumn{6}{|c|}{ Expenditure and Expenditure squared } \\
\hline $\operatorname{lnEXPD}$ & $\begin{array}{c}0.0665 \\
(0.0562)\end{array}$ & $\begin{array}{c}0.0444 \\
(0.0587)\end{array}$ & $\begin{array}{c}0.1079 * * \\
(0.0532)\end{array}$ & $0.1497 * *(0.0584)$ & $\begin{array}{c}-0.3686 * * * \\
(0.0309)\end{array}$ \\
\hline $\operatorname{lnEXPD}{ }^{2}$ & $\begin{array}{c}0.0054 * * \\
(0.0025)\end{array}$ & $\begin{array}{c}0.0002 \\
(0.0026)\end{array}$ & $\begin{array}{c}0.0025 \\
(0.0024)\end{array}$ & $\begin{array}{c}0.0067 * * * \\
(0.0025)\end{array}$ & $\begin{array}{c}-0.0149 * * * \\
(0.0017)\end{array}$ \\
\hline \multicolumn{6}{|c|}{ Household characteristics } \\
\hline SexHH & $\begin{array}{c}0.0126 * * \\
(0.0052)\end{array}$ & $\begin{array}{l}-0.00680 \\
(0.0066)\end{array}$ & $\begin{array}{l}-0.0060 \\
(0.0048)\end{array}$ & $\begin{array}{c}-0.0076^{*} \\
(0.0040\end{array}$ & $\begin{array}{c}0.0078 \\
(0.0059)\end{array}$ \\
\hline HHsz & $\begin{array}{c}-0.0010 * * \\
(0.0004)\end{array}$ & $\begin{array}{c}0.0004 \\
(0.0005)\end{array}$ & $\begin{array}{c}0.0005 \\
(0.0003)\end{array}$ & $\begin{array}{c}0.0005 \\
(0.0004)\end{array}$ & $\begin{array}{l}-0.0004 \\
(0.0003)\end{array}$ \\
\hline Yeduc & $\begin{array}{c}0.0001 \\
(0.0002)\end{array}$ & $\begin{array}{c}0.0003 \\
(0.0002)\end{array}$ & $\begin{array}{c}0.0001 \\
(0.0002)\end{array}$ & $\begin{array}{l}-0.0001 \\
(0.0002)\end{array}$ & $\begin{array}{l}-0.0003^{*} \\
(0.0002)\end{array}$ \\
\hline Accredit & $\begin{array}{c}0.0013 \\
(0.0018)\end{array}$ & $\begin{array}{c}0.0046 * * \\
(0.0023)\end{array}$ & $\begin{array}{l}-0.0002 \\
(0.0016)\end{array}$ & $\begin{array}{l}-0.0022 \\
(0.0019)\end{array}$ & $\begin{array}{c}-0.0034 * * \\
(0.0015)\end{array}$ \\
\hline IMR & $\begin{array}{l}-0.0157^{*} \\
(0.0090)\end{array}$ & $\begin{array}{c}0.0341 * * * \\
(0.0112)\end{array}$ & $\begin{array}{l}-0.0013 \\
(0.0077)\end{array}$ & $\begin{array}{l}-0.0137 \\
(0.0095)\end{array}$ & $\begin{array}{l}-0.0034 \\
(0.0069)\end{array}$ \\
\hline
\end{tabular}

Note:***,**,* indicate level of significance at $1 \%, 5 \%$, and $10 \%$ respectively. Standard errors are in parenthesis.

ln = Logarithm; LVs = leafy vegetable; FrVs = fruit vegetable; RBVs = root and bulb vegetable; HFs = herbaceous fruit; TFs = tree fruit; $\operatorname{lnEXPD}=$ logarithm of total fruit and vegetable expenditure; $\operatorname{lnEXPD}{ }^{2}=$ square of logarithm of total fruit and vegetable expenditure; $\mathrm{IMR}=$ Inverse Mills Ratio; SexHH = sex of household head; HHsz = household size; Yeduc $=$ years of schooling; Accredit $=$ access to credit facility.

Source: Estimates from QUAIDS model

Table 4: Determinants of demand for fruits and vegetables (Urban) (Continuation).

\section{Expenditure elasticity of demand for fruits and vegetables}

Expenditure elasticity captures the percentage change in the quantity demanded of a good with respect to a percentage change in total expenditure (Tomek and Robinson, 2003). The elasticities were estimated at the sample means for the fruit and vegetable groups considered in this study and were reported in the context of economic theory, where an expenditure elasticity in the range of zero and one signifies a commodity to be a 'necessary good', greater than one implies a 'luxury good', while less than zero (negative) implies an 'inferior good' (Adegeye and Dittoh, 1985). As shown in Table 5, expenditure elasticities for rural and urban households revealed a variation in their expenditure behaviour. For some fruit and vegetable groups, the difference in the estimated expenditure elasticities between rural and urban samples was quite substantial. For example, a 1 percent increase in expenditure will lead to a greater than proportionate increase (3.25 and 1.59 , respectively) in the quantity of root and bulb vegetables demanded by rural and urban households, while tree fruits was found to be negative for both rural and urban households, indicating that they are inferior goods (less than zero).

\begin{tabular}{lcc}
\hline Fruit and vegetable group & \multicolumn{2}{c}{ Expenditure elasticity } \\
\hline & Rural & Urban \\
Leafy vegetable & 1.1676 & 1.1593 \\
Fruit vegetable & 1.7456 & 1.1814 \\
Root and bulb vegetable & 3.2521 & 1.5908 \\
Herbaceous fruit & 0.3665 & 1.6853 \\
Trees fruit & -6.2779 & -1.3452 \\
\hline
\end{tabular}

Source: Estimates from the QUAIDS model

Table 5: Expenditure elasticities of demand for fruits and vegetables.

Compensated and uncompensated ownand cross-price elasticities of demand

The uncompensated demand also known as the Marshallian demand represents the conventional market or individual demand. It implicitly combines both income and substitution effects and in this case, income is held constant while an alternative approach to demand is known as the compensated or Hicksian demand which compensates a consumer for price change. That is, when the price changes, consumers receive compensation that allows them to remain on their original indifference curve. Generally, Marshallian estimates provide better measure of the responsiveness for any particular good to changes in its own price than to the changes in the price of other goods (Alam, 2011). The Hicksian elasticities is known to provide better 
estimates of substitution effects between two food categories, devoid of the income effect (Bundi et al., 2013).

Compensated and uncompensated own- and crossprice elasticities of demand are presented in Tables 6 and 7. The results in Table 6 and 7 revealed that all the uncompensated and compensated own-price elasticities, as shown in the diagonal matrix displayed appropriate negative signs, indicating the inverse relationship between prices of a commodity and its demand. This finding is consistent with economic theory. The uncompensated own-price elasticity estimates for rural households in Table 6 revealed that leafy vegetables and herbaceous fruits were priceinelastic in absolute terms (less than one), implying that their demand was less responsive to changes in own-price. The uncompensated own-price elasticity for other groups was price-elastic, while in the urban all fruit and vegetable groups were price-inelastic (Table 7). The implication of these results is that, demand for fruits and vegetables are more responsive to changes in own-prices in the rural and lesser in the urban. On the other hand, the uncompensated cross-price elasticities are mostly positive (Table 6) in the rural area indicating that most of the fruit and vegetable groups considered were net substitutes, however the reverse was the case among urban households (Table 7) indicating complementary relationships. Similarly, the compensated cross-price elasticities for rural and urban households were mostly positive (Table 6 and 7) indicating that most of the fruits groups were net substitutes in both rural and urban areas.

\begin{tabular}{lccccc}
\hline $\begin{array}{l}\text { Fruit and } \\
\text { vegetable group }\end{array}$ & LVs & FrVs & RBVs & HFs & TFs \\
\hline LVs & \multicolumn{5}{c}{ Marshallian/uncompensated elasticity } \\
FrVs & $\mathbf{- 0 . 4 6 1 0}$ & -0.7184 & -0.1417 & 0.1190 & 0.0237 \\
RBVs & -0.3209 & $\mathbf{- 1 . 2 7 9 7}$ & -0.2260 & -0.1676 & 0.2081 \\
HFs & -0.5305 & -2.1907 & $\mathbf{- 1 . 9 2 6 3}$ & -0.0891 & 1.7400 \\
TFs & 0.5525 & 0.6961 & 0.6544 & $\mathbf{- 0 . 9 0 5 1}$ & -0.5394 \\
& 1.7000 & 6.0734 & 2.1500 & 0.8297 & $\mathbf{- 4 . 0 3 6 8}$ \\
LVs & & Hicksian/compensated elasticity & & \\
FrVs & -0.1113 & 0.0273 & 0.2103 & 0.1256 \\
RBVs & $\mathbf{- 0 . 2 6 2 7}$ & $-\mathbf{0 . 3 7 2 2}$ & 0.0266 & -0.0311 & 0.3605 \\
HFs & -0.0244 & -0.4999 & $-\mathbf{1 . 4 5 5 7}$ & 0.1653 & 1.1300 \\
TFs & 0.0219 & 0.5055 & 0.6014 & $\mathbf{- 0 . 9 3 3 7}$ & -0.5714 \\
\hline
\end{tabular}

Note: $\mathrm{LV}=$ leafy vegetable, $\mathrm{FrV}=$ fruit vegetables, $\mathrm{RBVs}=$ root and bulb vegetables, $\mathrm{HFs}=$ herbaceous fruits, $\mathrm{TFs}=$ tree fruits Source: Estimates from QUAIDS model

Table 6: Own- and cross-price elasticities of fruit and vegetables (Rural).

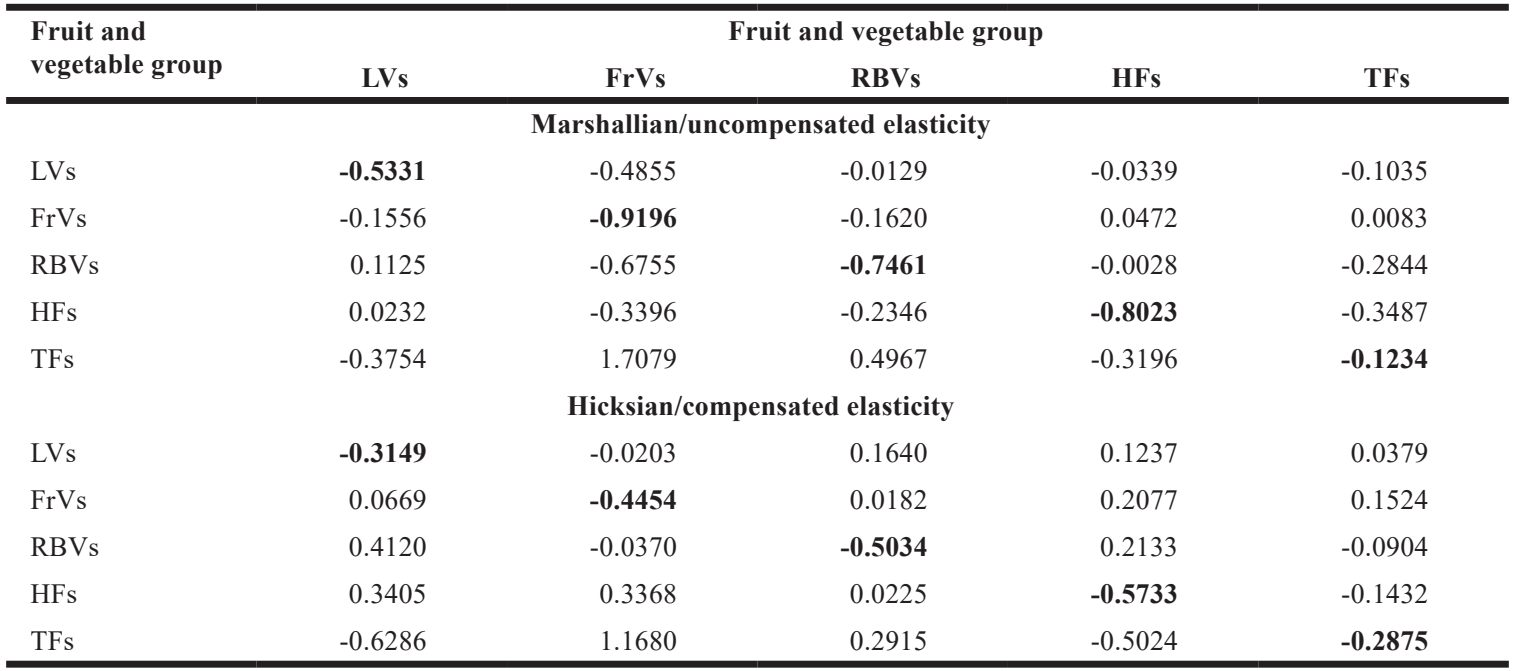

Note: $\mathrm{LV}=$ leafy vegetable, FrV = fruit vegetables, $\mathrm{RBVs}=$ root and bulb vegetables, HFs $=$ herbaceous fruits, $\mathrm{TFs}=$ tree fruits Source: Estimates from QUAIDS model 


\section{Conclusion}

This study addressed the question whether there are any disparities in fruit and vegetable expenditure behaviour between rural and urban households in Southwestern Nigeria using primary data collected between April and May, 2013. In order to correct for zero observations, a two-step estimation procedure developed by Shonkwiler and Yen (1999) was adopted. A Probit regression was estimated in the first stage, while the quadratic almost ideal demand system model was estimated in the second stage. Results show that the quantity of fruits and vegetables demanded by households are far below the WHO's minimum recommendation. Also, socio-demographic characteristics such as prices of fruits and vegetables, and household heads' years of education and access to credit play important roles in rural households' demand for fruits and vegetables. On the other hand, urban households' demand for fruits and vegetables are influenced by household size and household heads' sex, years of education and access to credit. All the fruits and vegetables were considered luxury goods among urban households, while it is a mixture of luxury and necessity goods in the rural. Tree fruits were considered 'inferior goods' in both rural and urban households. Rural households were more responsive to changes in own-price than their urban counterparts, while most of the fruits and vegetables were net substitutes among rural and urban households.

Corresponding authors

Dr. Rebecca Ibe

National Horticultural Research Institute, Jericho Reservation Area

Idi-Ishin P.M.B. 5432, Dugbe Post office Ibadan, Nigeria

Phone: 2348035850487,E-mail: beckkyibe2015@gmail.com

\section{References}

[1] Abdulai, A. and Aubert, D. (2004) "A cross-section analysis of household demand for food and nutrients in Tanzania”, Agricultural Economic, Vol. 31, No.1, pp. 67-79. E-ISSN 1805-9295, ISSN 0139-570X. DOI 10.1111/j.1574-0862.2004.tb00222.x.

[2] Adegeye, A. J. and Dittoh J. S. (1985) "Essentials of Agricultural Economics", University of Ibadan, Impact Publishers Nig. Ltd., Ibadan, 251 p. ISBN 9782386006.

[3] Akinleye, S. O. (2009) "Food demand in Northern Nigeria: Implications for food policy", Journal of Social Sciences", Vol. 18, No. 3, pp. 209-215. ISSN 2668-7798. DOI 10.1080/09718923.2009.11892683.

[4] Alam, M. D. A. (2011) "An analysis of consumption demand of elasticity and supply response of major food grains in Bangladesh", Thesis to meet requirements for the joint academic degree of International Master of Science in Rural Development from Ghent University (Belgium), Agrocampus Ouest (France), Humboldt University of Berlin (Germany), Slovak University of Agriculture in Nitra (Slovakia) and University of Pisa (Italy) in collaboration with Wageningen University (The Netherlands).

[5] Banks, J., Blundell, R. and Lewbel, A. (1996) "Tax Reform and Welfare Measurement: Do We Need Demand System Estimates?”, The Economic Journal, Vol. 106, No. 438, pp. 1227-1241. E-ISSN 1468-0297. DOI 10.2307/2235517.

[6] Banks, J., Blundell, R. and Lewbel, A. (1997) "Quadratic Engel Curves and Consumer demand", The Review of Economics and Statistics, Vol. 79, No. 4, pp. 527-539. E-ISSN 1530-9142, ISSN 0034-6535. DOI 10.1162/003465397557015.

[7] Banwat, M. E., Lar, L. A. Daber, J., Audo, S. and Lassa, S. (2012) "Knowledge and intake of fruit and vegetable consumption among adult in urban community in North Central, Nigeria", The Nigeria Health Journal, Vol. 12, No. 1, pp. 12-15. ISSN 1597-4292.

[8] Bundi, M. K., Nzuma, J. and Mbatia, O. L. E. (2013) "Urban demand for smaller crops: The case of fruits and vegetables in Nairobi, Kenya", paper at the $4^{\text {th }}$ International conference of the African Association of Agricultural Economists (AAAE), September 22-25, Hammamet, Tunisia, pp. 23. [Online]. Available: https://ideas.repec.org>ags>aaae13 [Accessed: 13 May 2015]. 
[9] European Food Safety Authority (2013) "The EFSA Comprehensive European Food Consumption Database". [Online]. Available: http://www.efsa.europa.eu/en/datexfooddb/datexfooddbspecificdata. htm [Aceesed: 22 June 2017].

[10] FAO (2006) "Food Security", In FAO Policy Brief: Food and Agriculture Organization of the United Nations. [Online]. Available: http://www.fao.org/forestry/13128-0e6f36f27e0091055bec28ebe830f 46b3.pdf [Accessed: 13 Dec. 2017].

[11] FAO (2013) “World Food and Agriculture”, Statistical Yearbook 2013, Food and Agriculture Organization of the United Nations, Rome, Italy. [Online]. Available: http://www.fao.org/docrep/018/ i3107e/i3107e00.htm [Accessed: 13 Dec. 201].

[12] Fashogbon, A. E. and Oni, O. A. (2013) "Heterogeneity in Rural Household Food Demand and Its Determinants in Ondo State, Nigeria: An Application of Quadratic Almost Ideal Demand System", Journal of Agricultural Science, Vol. 5, No. 2, pp. 169-177. ISSN 1916-9752, E-ISSN 1916-9760. DOI 10.5539/jas.v5n2p169.

[13] Global Environment Monitoring System (GEMS/ Food) (2012) World Health Organisation, 2015. [Online]. Available: http://www.who.int/nutrition/landscape_analysis/nlis_gem_food/en/ [Accessed: 22 June 2017].

[14] Izzah, N. A., Aminah, A., Pauzi, M. A., Lee, Y. H., Rozita, W. M. and Fatima, S. D. (2012) "Patterns of fruits and vegetable consumption among adults of different ethnics in Selangor, Malaysia", International Food Research Journal, Vol. 19, No. 3, pp. 1095-1107. E-ISSN 22317546.

[15] Matthew, I. P. and Karikari, S. K. (1990) "Horticulture principles and practices", Macmillan Intermediate Agriculture series (General editor: Ochapa O. Onazi), Macmillan Education Ltd., London. ISBN 0333453069.

[16] Muhammad-Lawal, A., Kolawole, F. L., Balogun M. A. and Jamiu, A. A. (2011) "Food demand analysis among rural households in Oyo state, Nigeria", International Journal of Food, Agriculture and Veterinary Sciences, Vol. 1, No. 1, pp. 45-50. ISSN 2277-209X.

[17] Mutuc, M. E. M., Pan, S. and Rejesus, R. M. (2007) "Household Vegetable Demand in the Philippines: Is There an Urban-Rural Divide?", Agribusiness, Vol. 23, No. 4, pp. 511-527. E-ISSN 1520-6297. DOI 10.1002/agr.20137.

[18] Nambiar, P. M., Florkowski, W. J., Chinnan, M. S. and Ressurrecion, A. V. A. (2014) "Factors driving fruit and vegetable expenditures and consumption frequency in lesser Developed Country: An analysis of urban households from the Republic of Uganda", Selected paper for presentation at the Southern Agricultural Economics Association Annual Meeting (SAEA), Dallas, TX, 1-4 February, $30 \mathrm{p}$.

[19] National Bureau of Statistics (NBS) (2012) "Consumption pattern in Nigeria 2009/10 preliminary report”, [Online]. Available: http://www.nigerianstat.gov.ng/pdfuploads/Consumption $\% 20$ Pattern\%20in\%20Nigeria\%202009-10.pdf [Accessed: 13 May 2014].

[20] National Population Commission (NPC) (2006) "2006 Population and housing census of the Federal Republic of Nigeria", Priority tables, Vol. I \& II. [Online]. Available: http://catalog. ihsn.org/index.php/catalog/3340/download/48519; http://catalog.ihsn.org/index.php/catalog/3340/ download/48520. [Accessed: 17 Nov. 2012].

[21] Ogundari, K. and Arifalo, S. F. (2013) "Determinants of household demand for fresh fruit and vegetable in Nigeria: A double hurdle approach", Quarterly Journal of International Agriculture, Vol. 52, No. 3, pp. 199-216. ISSN 00498599. DOI 10.22004/ag.econ.173646.

[22] Ogunmakinde, O. E. Oladokun, S. D. and Oke, O. E. (2015) "Rural-Urban Migration in South Western Nigeria: A Menace to National Development", Civil and Environmental Research, Vol. 7, No. 5, pp. 42-47. ISSN 2225-0514.

[23] Ogunniyi, L. T., Ajao, A. O. and Oladejo, J. A. (2012) "Food consumption patterns in Ogbomoso Metropolis of Oyo State, Nigeria", Journal of Agriculture and Social Research, Vol. 12, No. 1, pp. 74-83. E-ISSN 1595-7470. 
[24] Ohen, S. B., Umeze, G. E. and Inyang, E. O. (2014) "Consumer Purchasing Behaviour for Fruits and Vegetables among Civil Servants in Essien Udim Local Government Area, Akwa Ibom State, Nigeria", Food Science and Quality Management, Vol. 23, pp. 55-64. ISSN 2225-0557.

[25] Otunaiya, A.O. and Shittu, A. M. (2014) "Complete household demand system for vegetables in Ogun State, Nigeria", Agric. Econ. - Czech, Vol. 60, No. 11, pp. 509-516. E-ISSN 1805-9295, ISSN 0139570X. DOI 10.17221/46/2014-AGRICECON.

[26] Pem, D. and Jeewon, R. (2015) "Fruit and vegetable intake: benefits and progress of nutrition education interventions- narrative review article", Iran Journal of Public Health, Vol. 44, No. 10, pp. 1309-1321. E-ISSN 22516093, ISSN 22516085.

[27] Pennington, J. A. T. and Fisher, R. A. (2009) "Classification of fruits and vegetables", Journal of Food Composition and Analysis, Vol. 22: Supplement, S23-S31. ISSN 0889-1575. DOI 10.1016/j.jfca.2008.11.012.

[28] Pollak, R. A. and Wales, T. J. (1981) "Demographic variables in demand analysis", Econometrica, Vol. 49, No. 6, pp. 1533-1551. E-ISSN 1468-0262. DOI 10.2307/1911416.

[29] Ruel, M. T., Minot, N. and Smith, L. (2005) "Patterns and determinants of fruit and vegetable consumption in Sub-Saharan Africa: a multi-country comparison", the Joint FAO/WHO Workshop on Fruit and vegetable for Health, 1-3 September 2004, Kobe, Japan. [Online]. Available: http://cdrwww.who.int/dietphysicalactivity/publications/f\&v_africa_economics.pdf [Accessed: 13 Dec. 2017].

[30] Shonkwiler, J. S. and Yen, S. T. (1999) "Two-Step Estimation of a Censored System of Equations", American Journal of Agricultural Economics, Vol. 81, No. 4, pp. 972-982. E-ISSN 1467-8276. DOI $10.2307 / 1244339$.

[31] Tey, Y. S., Shamsudin, M. N., Mohamed, Z., Abdullah, A. M. and Radam, A. (2009) “Analysis of demand for vegetable in Malaysia”, MPRA paper No.15033, University Library of Munich, Germany. [Online]. Available: http://mpra.ub.uni-muenchen.de/15033 [Accessed: 18 Oct. 2014].

[32] Uusiku, N. P., Oelofse, A., Duodu, K. G., Bester, M. J. and Faber, M. (2010) "Nutritional value of leafy vegetables of sub-Saharan Africa and their potential contribution to human health: A review", Journal of Food Composition and Analysis, Vol. 23, No. 6, pp. 499-509. ISSN 0889-1575. DOI 10.1016/j.jfca.2010.05.002.

[33] Wang, X., Ouyang, Y., Liu, J., Zhu, M., Zhao, G., Bao, W. and Hu, F. B. (2014) "Fruit and Vegetable Consumption and Mortality from All Causes, Cardiovascular Disease and Cancer: Systematic Review and Dose Response Meta-Analysis of Prospective Cohort Studies", The British Medical Journal, 349, g 4490. ISSN 1756-1833. DOI 10.1136/bmj.g4490. 


\section{Appendix}

\begin{tabular}{ll}
\hline Category & Disaggregates of fruits and vegetables \\
\hline Leafy vegetables (LVs) & Green amaranth, slim amaranth, celosia, corchorus, and Fluted pumpkin \\
Fruit vegetables (FrVs) & Tomato, okra, bell pepper, red pepper, and egusi melon \\
Root and Bulb vegetables (RtBub) & Onion \\
Herbaceous/perennialfruits (HerFr) & Banana and pineapple \\
Tree fruits (TrFr) & Citrus and mango \\
\hline
\end{tabular}

Source: Compiled by author based on the classifications of Matthew and Karikari (1999) and Pennington and Fischer (2009) Table A.1: Construction of fruit and vegetable categories. 